\title{
Easter Island Under Glass: Observations and Conversations
}

\section{Lindley Kirksey}

Mysterious Easter Island? How the people will embrace the $21^{\text {st }}$ Century is the real mystery. Electricity arrived in the $70 \mathrm{~s}$, taxis and the Concorde in the 90s. And the Internet has just arrived. The beauty of the flowering African tulip tree and the serenity of a lone horseman crossing Tahai's ceremonial area at sunset remain as first impressions. One image represents the impact of introduced culture to the island; the other, the communion of man with his land. Both are key to an understanding of Easter Island today.

Easter Island, a province of Chile and the most remote civilized island in the world, is positioned approximately 2200 miles west of Chile and 1400 miles east of Pitcairn Island. Forty-two percent of Easter Island is National Park with most of the population living in the town of Hanga Roa, where island services are concentrated. The rise and collapse of the native civilization between about 400 $\mathrm{AD}$ and the first European contact in 1722 present unanswered questions: the Polynesian origin of the first settlers, the carving and movement of stone statues weighing up to 80 tons or more, the decline in the culture, and the depletion of natural resources. All have contributed to the mystery surrounding Rapa Nui.

As part of an interdisciplinary team sponsored by the Science Museum of Long Island and led by John Loret and Robert Hemm, I participated in a scientific update of the events that led to the precontact drop in population and overuse of natural resources. Today, no native trees exist on this once wooded volcanic island. A native population that once numbered over 10,000 people now has reached about 2000. At its lowest point, due to disease, lack of food, civil war, and slave raids, the population had fallen to a mere 111 . Such a rise, fall, and recent recovery in a society isolated from outside contact for over 1300 years suggests a model for the progress on Planet Earth-of man's interaction with his resources. In pondering this, I realized what a rare opportunity I had to roam this peaceful place and experience the openness and warmth of the Rapanui. The themes that reoccurred in conversations-spontaneous and arranged-about the island were land ownership and preserving a sense of personal freedom. I became aware that there is an appropriate role to be played by the developed nations in helping the Rapanui in their struggle for identity and survival.

How do the Rapanui experience themselves in the world? An early name for the island was Te Pito 'o te Henua, or Navel of the Earth. They feel themselves to be a special people and cherish their land. This is evidenced in how often they return: those who move to Tahiti or the continent imme- diately plan a return visit and many would prefer to die where they were born. The present is more real than the future, and myth and reality sometimes are interwoven. The island priest, Father Joe Navarrete, and H. Chivano, teacher of philosophy at the high school, both spoke of the importance of dreams and of the spirit world where good and bad spirits are given deference. Even today an elderly person may simply wander into the interior of the island to find a place to die-a place of clan significance such as a secret cave. Once the entire school turned out to look for a woman whose body was never found.

Friendships and business relationships depend on certain underlying structures affecting daily life, as they do with all people, and these need to be understood. Family life on the island can be a fluid arrangement. Many couples do not marry even though they may share a house and raise children. Most marriages today are mixed with one spouse being from off the island. This is understandable when one considers that almost all the people on the island are, by now, related and that cousins who marry can be ostracized by the rest of the community. Several women that I spoke with did not want to marry a Rapanui man because there can be domestic abuse between husband and wife. I heard this from many people, including the Catholic priest. Tribal custom dictated that the woman became the property of the man-a loss of freedom. A welfare system is not needed on the island as the tribal system is also a support system. Women often follow the Chilean custom of keeping their maiden name. This also serves to preserve clan recognition. For a child, all aunts and uncles are parents and all adults are aunts and uncles. A child may go from home to home for any number of reasons, residing there as a member of the family - fed and cared for. Accustomed to having the run of the whole island, school children - who live in constant contact with the environment-pose disciplinary problem for the teachers and are defended in their freedom to roam by parents and guardians.

Discipline issues aside, parents are genuinely interested in the education of their children. Eight hundred students attend grades kindergarten through grade twelve. Most finish high school and some receive scholarships to go to college in Chile. The Chilean government is encouraging unique, regional approaches to curriculum development, a concept that may well preserve the cultural heritage of the Rapanui. Parents and staff are meeting now to address these critical areas: preparation for university, personal relations, environment, preservation of the island, awareness of old people, respect, and preservation of the language. Language in general is a 
major concern. In the home, both Spanish and Rapanui are often spoken. Recently, English has been required through grade twelve and French is an elective. Many islanders have ties in Tahiti, and at least French and some Japanese language skills are picked by those engaged in the active tourist business.

According to Father Joe Navarrete, the islanders are good church attendees - for 100 years most islanders have been Roman Catholic - though many do not observe the sacrament of marriage. I observed children learning to sing the hymns, most of which are in Tahitian and attended the family service. The Mass is in Spanish and some Rapanui. Ten songs are in Rapanui. This mixture of language and culture extends to the carved wooden statues that adorn the church. Carved in the island tradition, they contain symbols from the ancient cult of the Birdman, an image that emerged at a time when civil war and hunger were prevalent. The warm, mellow tones of the wood are in contrast to traditional Spanish-Catholic religious statuary.

There are no homeless on Easter Island and no begging children. To compensate, the informal system is based on a sharing of items and services. A colorful example is this: a man may request of another a pack of cigarettes - the entire pack,

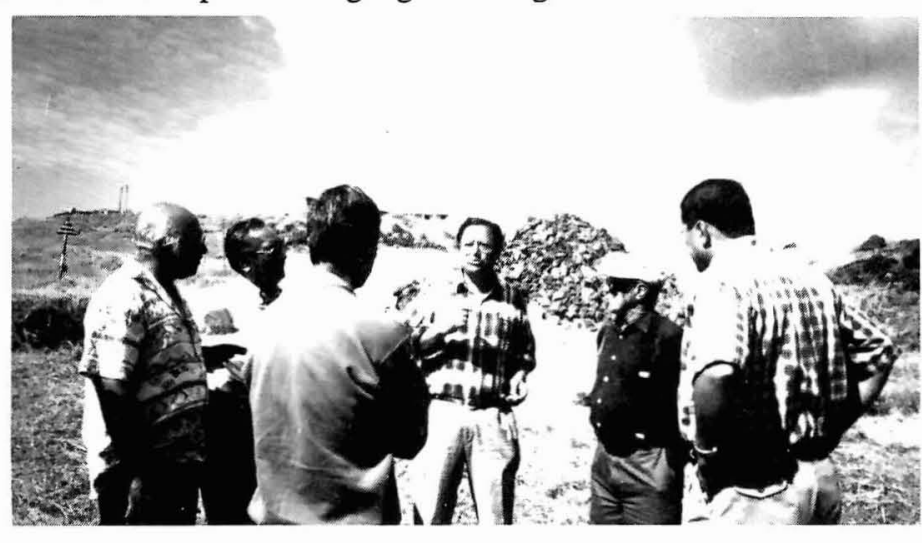

Sergio Rapu (center) discussing plans to restore the $a h u$ at Hanga Piko. On the right are Dr John Loret and Alcalde Petero Edmunds.
Land really is the issue on Easter Island. With 10,000 tourists arriving by plane or ship each year and with almost half the land deemed national park, the management of this fragile resource is at the heart of the economy and future of Easter Island. The Corporacion National Forestal, CONAF, is the department of the central government of Chile that administers the Rapa Nui National Park. Approximately 20 people are on the staff on Easter Island. Marcos Rauch Gonzalez, the archaeologist and second in command, spoke candidly about the need for training in conservation of sites and in interpretation of both the archaeology and the environmental issues. Over 800 statues (moal) mostly carved from volcanic tuff, and 300 ceremonial platforms $(a h u)$ plus over 5000 petroglyphs, quarries, volcanic caves, and other sites are under the protection of the park system. Livestock,

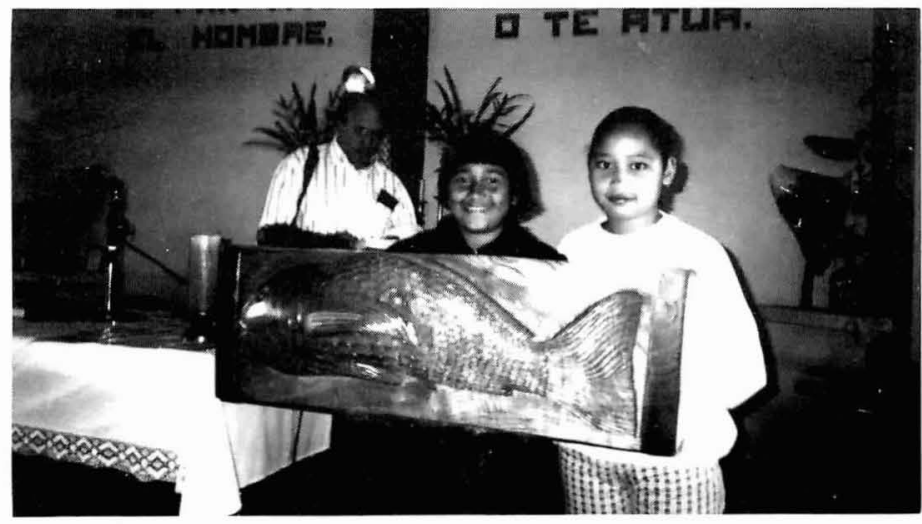

Rapanui children in the island's Catholic Church. The elegant fish on the wood lecturn was carved by local artists. tourists, and local people roam freely about the island leaving sites in the middle of fields especially vulnerable. Animals are particularly destructive, as is fire. In 1996, a fire in the volcanic crater Rano Raraku scarred one moai and affected 46 others. The lone park ranger could not call for help because CONAF personnel on the island do not have radio transmitters.

Three locals have onsite rangers: 'Orongo, a cerenot just one cigarette. If the owner has a pack, he will no doubt give it over. A few weeks later, the giver may be helped with a tire repair on the road by the receiver of the pack of cigarettes. This concept of asking is complex and pervasive. All manner of jobs and favoritism go first to one's kin. Ownership of land is confined to those of Rapanui decent and no taxes are collected. The island is administered as a province of Chile with an appointed governor and an elected mayor and council members. The islanders therefore feel both protected and provided for and at the same time prevented from the free use of their own land and from the planning of their own destiny. Fishing and tourism are the main income sources for the island and since approximately 90 babies are born each year, I asked Mayor Pedro Edmunds Paoa if he felt that land would become scarce. With a smile, he informed me that Easter Island is the size of Hong Kong and that land parcels could be given out for 200 years. In the middle of the Pacific Ocean as it is, it is-not likely that Easter Island will become the hub that Hong Kong is, but I got the point. monial center connected with the Birdman cult; Rano Raraku, the quarry where the massive statues were carved in one piece from volcanic tuff; and 'Anakena, the beach where Hotu Matua, legendary founder of the Rapanui people, is said to have landed. Even with an on-site ranger, theft and vandalism are hard to prevent for the role of ranger is not that of a policeman. At 'Orongo, the interpretation plaques were stolen and a rare artifact from the Easter Island Museum was taken by a young boy who smashed it in his escape. Knowing that visitors like "discovery", animal bones are sometimes deposited in niches at the ceremonial sites where the dead were once buried. There is an interesting forerunner to this activity. During Thor Heyerdahl's expedition in 1955, islanders would work all night to produce the desired "secret cave" artifacts, appropriately distressed.

This is not a case of disinterest from the outside world. Easter Island is one of the most studied places on earth. UNESCO and the World Monuments Fund have provided funds for studies and restoration projects, and recognize that 
heritage and preservation of the island's treasures are international concerns. Sergio Rapu, archaeologist, local businessman, and former Governor of the island, would like to see park people trained in the American park system through funds sent directly to the island. Too often, up to $50 \%$ of funds designated for Easter Island remain in Chile for administrative purposes. Because the municipal law permits the city to form an outside non-profit corporation, the Mayor and Sergio Rapu both support setting up a foundation funded by private enterprises to be managed for the benefit of Easter Island and the National Park System. A council would determine where and how the income would be spent. Preservation is not a casual undertaking. To restore the monument at 'Anakena it took $\$ 400,000$. Fourteen years ago, $\$ 16,000$ was spent to preserve one statue. This activity is on hold because the consequences of preservation are not known, and because the cost of treatment is high.

Something should be mentioned about stone conservation - a controversial issue. Most of the large moai on Easter Island are carved from volcanic tuff and are showing serious deterioration. Though spared the ravages of freezing weather, the winds, rain, and salt water are constant and take a toll. Applying a coating to stone can form a barrier to the elements and protect stone for a while. Various alkoxysilanes are often the choice and these consolidate the stone by forming a bonding with the surface. The idea is to keep out moisture and preserve the surface. A successful conservation project was carried out on one moai at Hanga Kio'e. Further restoration has been deterred because of unanswered questions: What happens ten years from now? Can the process be undone? Will wear occur unevenly and leave a blotched effect? Part of the process of time is that all things age. An alternative to massive (literally) restoration projects would be to enclose some statues, make models of certain statues, and record accurate information on film and in writing using sophisticated equipment. Objects can be scanned and recorded in digital form. Excellent material on this topic can be found in the publications of The Getty Conservation Institute and those of the World Monuments Fund, specifically, Easter Island: The Heritage and its Conserva-

\section{P.}

In considering the economics of life on Easter Island in the next century, it is important to see the need to further the development of tourism and also to expand income producing activities for the islanders who hunger as much as the rest of the world for refrigerators and TV's. The soil is thin, erosion a problem, and fresh water is found only underground, or in the volcanic craters or catchment water holes. With frequent airplane deliveries, islanders often spend more on imported foods than on the local produce. To Sergio Rapu suggests the founding of a technical institute on the island to train young people in the history and archaeology of the island and in private enterprise. Again, this is seen as a road to freedom. Since 1966, islanders can vote and travel, but

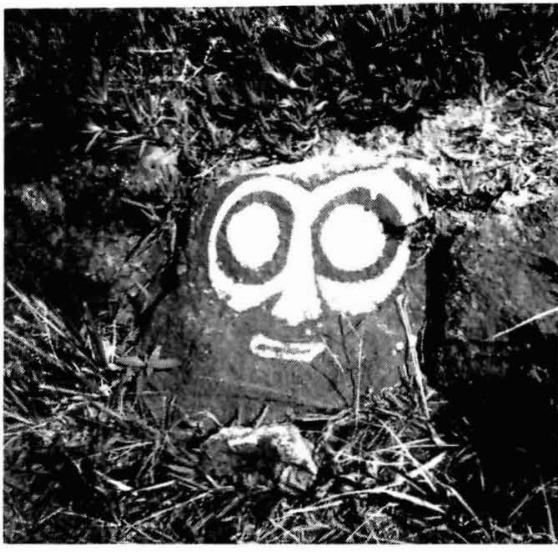

A Makemake face painted by local islanders for the benefit of tourist cameras. they cannot sell their own land or go to the bank and take out an equity loan. Sergio would like to introduce the technology of growing hydroponic vegetables, and an authority on this process has already visited the island from Israel. Sergio would also like to train young people to be "archaeological technicians"-able to speak with authority about the island's treasures.

No one on Easter Island is rich, and those who are well off are in the tourist business. To boost economic development, Mayor Paoa is encouraging the best of the island's carvers to produce the elegant walking canes that include ancient motifs and is undertaking a tour to secure upscale markets for these products in the United States. Because visitors seldom stay on the island more than three days, the Mayor also wants the island to offer walks to the less accessible sites, trail rides for horseback riders, and nature and bird address these issues, watching outings. Certain monument sites, with the sea beyond, lend themselves as outstanding outdoor performance areas for use by the local people as well as the tourists. I would hope that a park plan would include a welcome center in Hanga Roa where accurate and specific information and videos, all in a number of foreign languages, would orient visitors and equip
A group of preschool children on an outing in Hanga Roa's small park. A Chilean monument can be seen in the right background: the statue represents Policarpo Toro, whose bones are interred here. them for outings on this unique island.

Another economic issue for Rapa Nui is the lack of a deep water port. Tourists arriving by ship must be ferried from the ship to the island, and lighters are used to bring in goods from container ships arriving from the continent about three times a year. It costs as much to have the lighter bring the containers from the ship as it does to bring the ship 2200 miles from the continent. Plans are to build a new deep water port at La Pérouse Bay, on the northwest coast. An article in Rapa Nui News (see the Easter Island web page on the Internet) reports that the proposal has 
the island divided between those wanting "progress" and those who want to preserve the pastoral beauty of the natural area-and one that the tourists come to see. Some feel that the already existing port at Hanga Piko should be expanded to accommodate larger ships.

This division on the issue of a new port is but one example of internal strife that can flare up at any time over large and small issues. A major division at the moment concerns the Council of Elders. A second Council was formed in opposition to the policies of the first, so now there are Councils $\# 1$ and \#2. One might think that the old tribal warfare has broken out again, rupturing families and pitting cousin against cousin. It would seem that

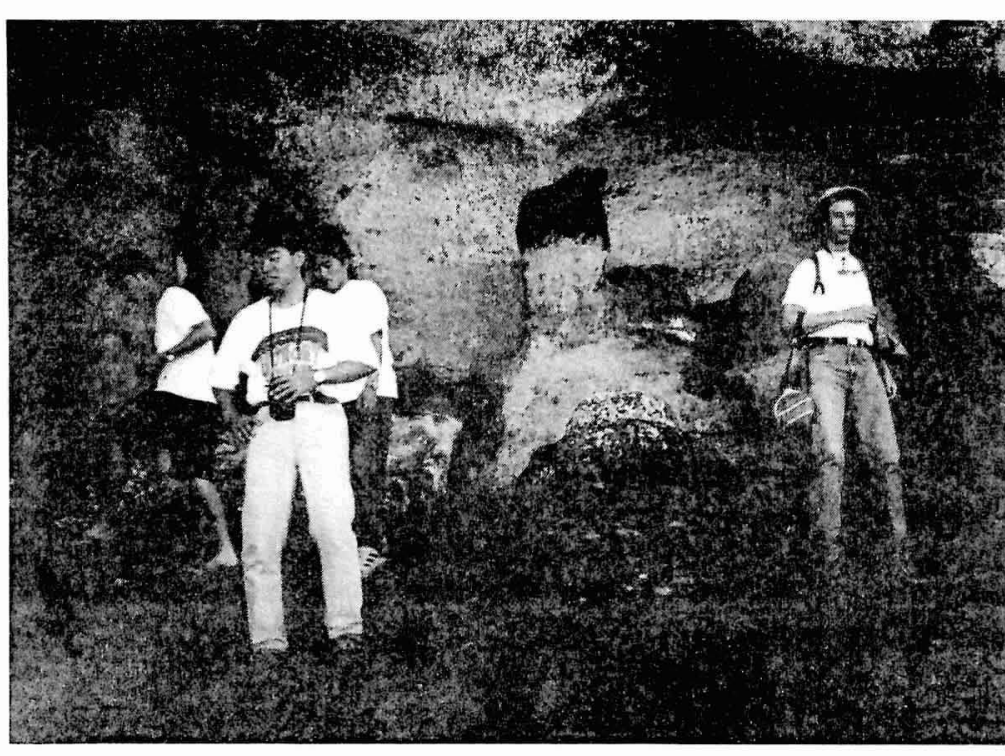

Tourists at Rano Raraku's statue quarry climb and walk on the statues that still lie in the rock; there are no barriers and little supervision.
Fortunately for the rest of the world, the Rapanui have a strong identity that they fight to preserve. This is in concert with their natural desire to acquire the benefits of the modern world-no small undertaking in a place where a pair of blue jeans costs $\$ 70$ US. With off-island marriages and fewer children speaking Rapanui at home, it is reassuring to witness their desire to preserve the language and history (as seen in the Tapati Festival). Some of this motivation may be economically driven as the islanders know well the lure the mysterious island has for the tourist. International organizations also recognize the need to help preserve this remarkable heritage.

Change will come to the island. It is desired, hot tempers and infighting among the islanders have to be ameliorated before the Chilean Government eases its control of the island's affairs.

Another area of particular concern to me was the lack of knowledge young adults on the island have of historical events and of volcanism. When asked about some aspect of the island, the secret caves, for instance, they are apt to give an answer from their ancient mythology with no awareness of how the caves were formed or that they were places of refuge when slave hunters visited the island and in times of civil strife. In his book, Rapanui: Tradition and Survival on Easter Island, anthropologist Grant McCall mentions being asked by a highly-educated Rapanui man if the Peruvian slavery really took place. This poses an interesting question. In this age of revisionist history, is it possible to give the Rapanui, who experienced extreme exploitation, a history they can be proud of? Perhaps this can be eased by defining acts of courage and by emphasizing the positive characteristics that continue to sustain the Rapanui who have survived. necessary, and inevitable. I learned that 150 toromiro trees, reintroduced to the island by well-intentioned botanists in Bonn, had all died. I could not resist the idea of Easter Island as the world's terrarium. In the effort of preservation, care must be taken to help-but not to impose-while leaving the destiny of the Rapanui in their own hands.

\section{REFERENCES}

Charola, A. E. 1994. Easter Island: The Heritage and its Conservation. World Monuments Fund: New York.

Fischer, Steven Roger, ed. 1993. Easter Island Studies. Oxbow Books: Oxford.

McCall, Grant. 1994. Rapanui: Tradition and Survival on Easter Island. University of Hawaii Press: Honolulu.

Price, C. A. 1996. Stone Conservation: An Overview of Current Research. The Getty Conservation Institute: Santa Monica, CA, 